\title{
Contributions of the urban metabolism concept and approach to cost assessments of environmental decisions
}

\author{
Eugenia Aumond Kuhn, Miguel Aloysio Sattler, Lucas \\ Dorneles Magnus
}

\section{Eugenia Aumond Kuhn}

Arquiteta (UFRGS); Doutora em Engenharia Civil (UFRGS); professora do Centro Universitário Ritter dos Reis - UniRitter; eugeniaakuhn@gmail.com

\begin{abstract}
Miguel Aloysio Sattler
Engenheiro Civil e engenheiro Agrônomo; Doutor (University of Sheffield) e pós doutor (University of Liverpool) em Ciências Ambientais Ligadas à Edificação; professor titular do Programa de PósGraduação em Engenharia Civil (UFRGS); masattler@gmail.com
\end{abstract}

\section{Lucas Dorneles Magnus}

Graduando em Arquitetura e Urbanismo; Universidade Federal do Rio Grande do Sul (UFRGS); lucas.magnus@ufrgs.br

\begin{abstract}
The concept of urban ecology is linked to the concept of urban metabolism that tries to estimate the interference of urban systems in the stability of flows of materials and energy historically established in the biosphere. Both concepts originated in the mid-twentieth century and spread internationally. A literature review on more than 20 scientific articles, written over the past decade identified the metabolic approach being applied to cities, municipalities and metropolitan areas. The growing number of research is due to the consolidation of international action plans for sustainable development. It was also identified that most of the researches were developed in the European context, where a standard method begins to be established. The absence of such type of studies in Latin America fomented the doctoral dissertation of the first author of this article, in which the first characterization of material flows associated to the metabolism of a Brazilian municipality was carried out (municipality of Feliz, State of Rio Grande do Sul). An extensive search led to data identification and collection, as well as to the development of specific methodological procedures for their treatment. From the results obtained and methodological procedures developed, this article aims to discuss potential contributions of the urban metabolism concept and approach to the assessment of the costs of environmental decisions in Brazilian settings. Contributions are made by: a) an analysis of the relationship between urban ecology, urban metabolism and assessment of environmental costs; b) the identification of the decision-making activities whose results it could support; c) the analyses of the possibilities and limitations to characterizing the metabolism of Brazilian cities and d) a discussion on future developments in this area of research.
\end{abstract}

Keywords: urban ecology . urban metabolism. urban sustainability.

\section{Resumo}

Intrinsecamente associado ao conceito de ecologia urbana está o de metabolismo urbano, o qual dá origem a pesquisas com o intuito de estimar a interferência dos sistemas urbanos na estabilidade dos fluxos de materiais e energia da biosfera. Ambos os conceitos, originados em meados do século $X X$, difundiram-se internacionalmente. A partir da revisão bibliográfica em bases de artigos científicos identificaram-se mais de 20 estudos, conduzidos na última década, aplicando a abordagem de metabolismo a municípios e 
regiões metropolitanas reais. O crescente número de pesquisas se deve à consolidação de planos de ação internacionais para o desenvolvimento sustentável. Apesar da profusão de pesquisas recentes, a maior parte das iniciativas é desenvolvida no contexto europeu, contando, inclusive, com um método padrão a orientá -las. A lacuna de estudos de cidades latino-americanas fomentou a tese de doutorado da primeira autora deste artigo, na qual se realizou a primeira caracterização dos fluxos de materiais associados ao metabolismo de um município brasileiro (caso de Feliz, RS). Para tanto, fez-se um extenso trabalho de identificação e de coleta de dados e o desenvolvimento de procedimentos metodológicos específicos para seu tratamento. O presente artigo tem por objetivo, a partir dos resultados obtidos e dos procedimentos metodológicos desenvolvidos, discutir as potenciais contribuições do conceito e da abordagem de metabolismo urbano para avaliação do custo das decisões ambientais no contexto brasileiro. Esperase contribuir com o tema através: a) da análise das relações entre ecologia urbana, metabolismo urbano e avaliação de custos ambientais; b) da identificação das atividades de tomada de decisão as quais os resultados obtidos poderiam oferecer suporte; c) da análise das possibilidades e limitações ao se pretender caracterizar o metabolismo de um número maior de municípios brasileiros e d) de uma discussão dos desenvolvimentos futuros neste tema de pesquisa.

Palavras-chave: ecologia urbana. metabolismo urbano. sustentabilidade urbana.

\section{Resumen}

El concepto de la ecología urbana esta relacionado con el concepto de metabolismo urbano, lo que conduce a la investigación con el fin de estimar la interferencia de los sistemas urbanos en la estabilidad de los flujos de materiales y energía en la biosfera. Ambos conceptos se originaron in la segunda mitad del siglo $X X$ y se extendió a nivel internacional. A partir de una revisión de la literatura, se identificaron más de 20 estudios realizados durante la década pasada, la aplicación del enfoque metabólica a las ciudades, municipios y áreas metropolitanas. El creciente número de investigaciones se debe a la consolidación de los planes de acción internacionales para el desarrollo sostenible. A pesar de la reciente profusión de investigación, la mayoría de las iniciativas se desarrollan en el contexto europeo, donde un método estándar empieza a ser establecido. La laguna de estudios de ciudades de América Latina fomentó la tesis doctoral del primer autor de este artículo, en el que la primera caracterización de información de flujos de materiales asociados con el metabolismo de un municipio brasileño se llevó a cabo (Feliz, RS). Por lo tanto, se llevó a cabo un extenso trabajo para la identificación y recopilación de datos, así como el desarrollo de procedimientos metodológicos específicos para su tratamiento. A partir de los resultados obtenidos y los procedimientos metodológicos desarrollados, este artículo tiene como objetivo discutir las posibles contribuciones del concepto y enfoque relacionado con el metabolismo urbano para evaluar el costo de las decisiones ambientales en el contexto brasileño. Las contribuciones se hacen mediante: a) el análisis de la relación entre la ecología urbana, metabolismo urbano y la evaluación de los costos ambientales; b) la identificación de las actividades de toma de decisiones cuyos resultados podrían apoyar; c) el análisis de las posibilidades y limitaciones para caracterizar el metabolismo de un mayor número de ciudades brasileñas y d) un análisis de la evolución futura de esta área de investigación.

Palabras clave: ecología urbana. metabolismo urbano. sostenibilidad urbana. 


\section{Introduction}

T he concept of urban ecology came into currency sometime around 1960 in a scenario of critical reflections on economic growth and its effects on the environment, which were accompanied by the consolidation of the field of ecosystems ecology. At the time, the industrial city model started to attract harsh criticism, as illustrated by the work of Mumford (1961), who denounced the myth of megalopolis and was joined by other contemporaries in anticipating the conflicts that would plague industrial cities.

Since then, the notion of sustainability has acquired growing importance in international discussions on development. In addition, researchers such as Costa (1999) claim that a significant part of this debate in developed countries is focused on the role of cities. Evidence to back this claim can be found in the Habitat Agenda (1996), one of the major international action plans to support sustainable development.

Silva (2000), however, points out that even though there is apparent consensus on the recognition of the problems affecting modern societies and cities and the urgency to solve such problems, this consensus soon disappears once objective proposals are called for. More specifically, with regard to the environmental dimension this difficulty is associated, inter alia, with the gap in knowledge on how and to what extent different local systems, patterns and activities (municipal or urban) affect natural systems at a local, regional and global scale (ALBERTI, 1996).

Research studies in the field of urban ecology use different approaches to try and provide some answers, of which one of the most popular is the concept of urban metabolism. This approach attempts to estimate the interference of urban systems in the stability of flows of materials and energy in the biosphere.

There is a growing number of recent studies that have adopted the urban metabolism approach. However, most have been conducted in European settings and make use of a standard method for guidance. Conversely, studies on the metabolism of Latin American cities are rare and this gap was one of the prime motivators for the doctoral dissertation of the first author of this article (KUHN, 2014), a pioneering characterization of material flows associated with the metabolism of a Brazilian city (Feliz, a city in the southern Brazilian state of Rio Grande do Sul). 
This article aims, from the results obtained and the methods developed by the Kuhn (2014), to discuss potential contributions of the urban metabolism concept and approach to the assessment of the costs of environmental decisions in Brazilian settings. It is expected that this aim will be achieved by means of three discussions. The first, developed in section 2, presents an analysis of theoretical contributions and investigates the relationships between the concepts of urban ecology, urban metabolism and environmental cost assessments. The second is an attempt to identify practical contributions based on the identification of decision-making activities which could be supported by the results of metabolism studies (section 3 ). Following that, in section 4, the possibilities and limitations affecting the characterization of metabolism in larger numbers of Brazilian cities are analyzed. Finally, the article summarizes potential future developments in this field.

\section{Relationships between urban ecology, urban metabolism and assessment of environmental costs}

\section{Development and state of the art of the studies on the field of urban ecology and urban metabolism}

The phrase 'urban ecology' has been used since the beginning to refer to two major lines of research investigating different urban phenomena. One originated in the 1920s and acquired significant prominence through the work of the so-called 'Chicago School', which developed sociological studies in the field of human ecology applied to phenomena associated with the growth of large cities, particularly in the United States (CIDADE, 2012).

A second line of research emerged in the 1960s and originated from the transposition of discussions in the ecology of ecosystems field that derived from the General Theory of Systems developed in the mid-twentieth century (FISCHER-KOWALSKI, 1998). This concept of urban ecology stems from a view of the city as an ecosystem in the broadest sense: 'an environmental unit within which all environmental elements and processes are interrelated and interdependent in such a way that a change in one of them results in changes in other components' (MOTA, 1981, p. 15).

It is this second line of research that advanced the concept of urban metabolism, which stems from a 
recognition that urban systems, like natural systems, have their own metabolism. Wolman (1965) was the first to attempt to translate this into an working concept that could be used to understand urban systems and quantify material and energy inputs and outputs in a hypothetical American city with a population of one million.

For Broto, Alen and Rapoport (2012), the key innovation in Wolman's study in urban ecology was that it represented a move from studies of the 'ecology in cities' to studies of the 'ecology of cities'. While the former focused on explaining how ecological patterns and processes within city limits are different from those in 'natural' environments, the latter emphasized how cities process matter and energy relative to their surroundings. This last perspective characterizes the city as an ecosystem embedded in a larger system and employs the concept of metabolism to describe the interactions between subsystems within an urban region (BROTO; ALLEN; RAPOPORT, 2012).

The first texts on urban ecology received worldwide support and this led UNESCO - the United Nations Educational, Scientific and Cultural Organization - to conduct the Man and Biosphere program, launched in 1971, whose scope comprehended a detailed analysis of Rome, Barcelona and Hong Kong. However, interest in the application of the concept of metabolism waned in the 1980s. There was an international symposium on urban metabolism in Japan, in 1983, but few of the papers were published. The only one found noteworthy was introduced by Girardet (KENNEDY; PINCETL; BUNJE, 2011), in which the 'linear metabolism' of the cities was identified as the major cause of the transference of environmental impacts from the cities (where resources are consumed at a high rate in the cities, metabolized and then eliminated as waste) to other regions. The key to reducing such impacts would be to create a 'circular metabolism' in which both the consumption of resources and the emission of waste would be reduced. This approach was rediscovered in the 2000s by Rogers and Gumuchdjian (2014), who adopted 'circular metabolism' as one of the paradigms of the sustainable city model.

From the early 1990 s, studies on the application of metabolism to cities started to resurface gradually and then experienced exponential growth after the 2000s. A review of the literature in scientific databases shows over 20 studies that applied the metabolism approach to cities, municipalities and metropolitan regions in the last 16 years. In addition, in 2007 the Journal 
of Industrial Ecology devoted a full issue to the metabolism of cities, including ten theoretical papers from authors of different fields of study (BAI, 2007).

This growth is directly linked with the consolidation of international action plans for sustainable development. It follows that researchers such as Kennedy and Hoornweg (2012) state that if local governments truly wish to adopt it, then data collection on urban metabolism has to become a permanent activity and more cities must start assessing their environmental performance.

This perspective shift toward a local territorial scale and, more specifically, toward cities, is due to the recognition that significant pressures, particularly of an environmental nature, originate in them and spill over their boundaries to affect both neighboring areas and distant regions in the globe (BAI, 2007). The so-called shortening of distances that comes with modern transportation systems, the expansion of globalized markets and the transfer of the industrial logic toward primary activities have increased the complexity of the relationships between cities, between cities and their surrounding rural areas and between the cities and the environmental processes that support them on a local, regional and global scale.

With regard to the methodological implications of the concept of metabolism, it can be observed that most urban metabolism studies in the last decade adopted the Eurostat Methodological Guide (EUROSTAT, 2001), a system that was originally developed to assess the physical metabolism of European national economies. Most studies were thus conducted in Europe, with each study proposing adaptations and modifications to the Guide to apply it to the city scale using the data available in a given context. An additional reason for the use of the Eurostat Methodogical Guide is that it standardizes flow categories and procedures developed, so that metabolism results can be compared between different cities. In addition, the Guide also proposed a set of indicators associated with environmental accounting.

It is worth noting that in all these studies, the unit of analysis is delimited by the administrative boundaries of the region under study. Therefore, most studies encompass regions that are roughly equivalent to municipalities or metropolitan regions in Brazil

The only studies on urban metabolism in Brazil were conducted by Conke and Ferreira (2015), for the city of Curitiba, and by Kuhn (2014), for the city of Feliz, in 
the southern state of Rio Grande do Sul. The metabolism of Curitiba is investigated from a reduced number of specific flows that are representative of global metabolism. These authors adopted a simplified method proposed by Kennedy and Hoornweg (2012) in the scope of what they call Abbreviated Urban Metabolism Studies.

The Feliz study adopts the general procedures and the flow classification proposed by the Eurostat Methodological Guide method as guidelines for the collection of data. Thus, all normal flows of human origin that enter or exit the city (captured by official sources or in statistics) were investigated. This method requires a comprehensive compilation of the input and output flows in the system. On the input side, the local extraction and imports from other cities, regions or countries were estimated. Outputs include residues, liquid waste, airborne emissions and exports to other cities, regions or countries.

Obtaining data on imports and exports of cities is a particularly challenging task. As an alternative in the Brazilian context, a set of procedures was developed to extract data from 'Notas Fiscais - eletrônicas' (NFe), a system of digital invoices, which makes use of an automated Java conversion application. These procedures are shortly presented in this article, but can be examined in detail in Kuhn (2014).

The sources for extracting these data were provided by the Rio Grande do Sul State Department of Revenue, as a set of Excel spreadsheets that listed all products traded between enterprises in Feliz and other cities, in the year 2011. Due to the fact that all transactions were disaggregated to the level of individual product, occurring in each commercial transaction, and to the fact that they were recorded in different measurement units, the procedures required, first, the units of measurement to be converted to metric tons. Subsequently, they were classified using their Common Mercosur Nomenclature (NCM) Code and the Eurostat Methodological Guide, according to their: a) processing level; b) composition; and c) position, chapter and upper section in the NCM framework.

Figure 01 shows results in their highest clustering level, according to their main composition. Other graphs and diagrams were prepared from different forms of classification. The method also allows individual products to be analyzed (input, output and consumption of gas or cement, for instance) and indicators can be calculated to allow comparisons between cities (see example in section 3.2). 


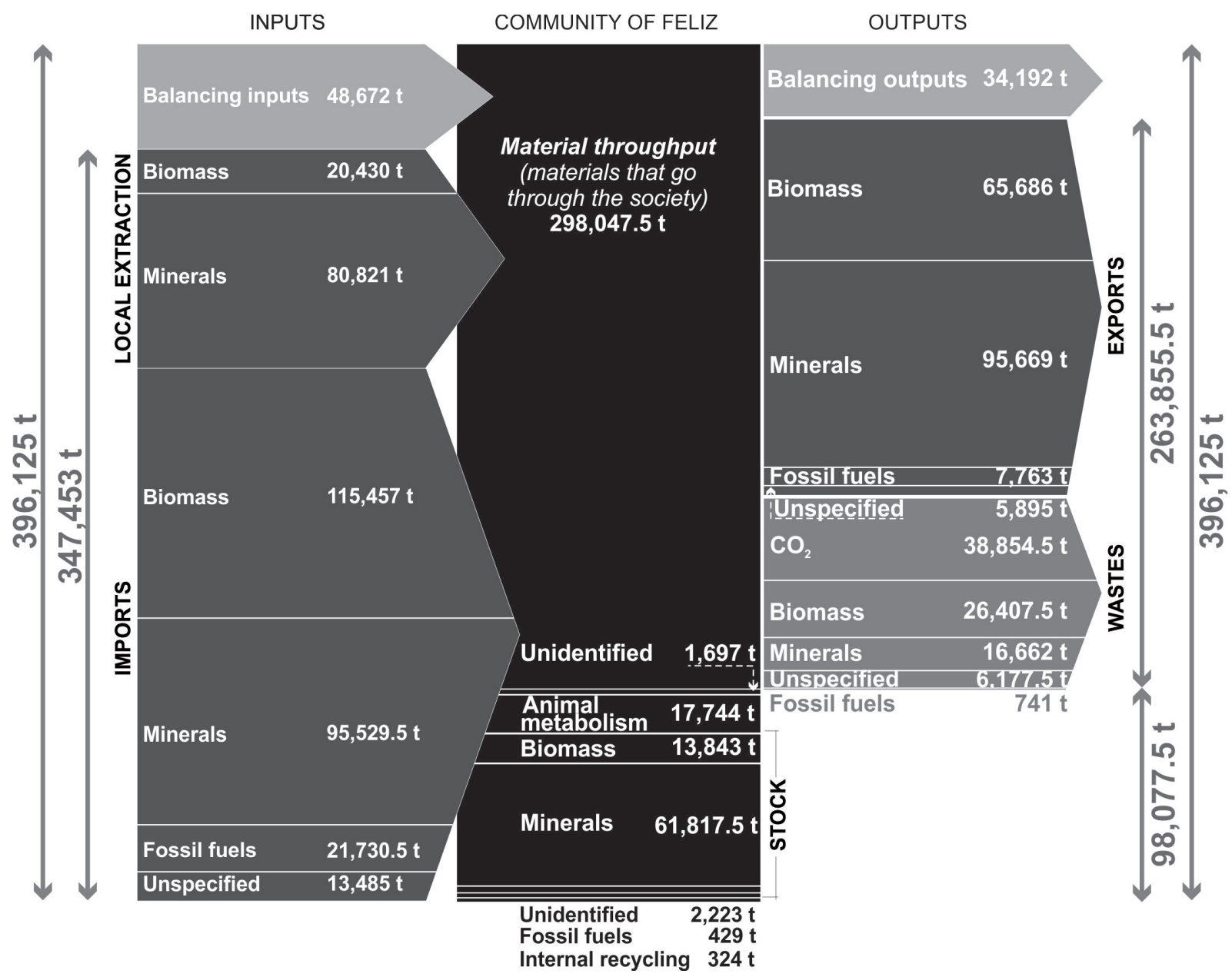

Figure 1

Material flows in the city of Feliz in 2011, divided by composition, in metric tons.

Source: Kuhn, 2014 (publication authorized by the author).

\section{Urban metabolism and environmental costs}

According to the concepts presented in the previous section, cities can be considered open systems that rely on the external environment to play some of their roles. This can be achieved by the provision of resources and the assimilation of waste (BAI, 2007). All the resources required by the system are called inputs, which can be extracted from the local environment or can reach the system through other systems (other cities, for instance). Materials that are extracted and processed locally, to be later exported, as well as the materials leaving the system after 'metabolization', are called outputs.

All the interactions between the system and the environment are expressed as flows of mass, which can be seen as cause and effect chains. These sequences result from processes and human activities that play some sort of environmental load. These, in turn, result in a series of intermediate mechanisms that will, ultimately, determine their final environmental 
impact. Such environmental loads, which constitute direct process outputs, result from resources consumption or emissions generation that are identified in metabolism studies. Their immediate consequences are known as environmental effects, which can be referred to as a primary response by the surrounding environmental system. Finally, the environmental impacts are a result of environmental effects and usually involve some form of apparent loss or gain to society, to a group of concern or to an individual (IEA ANNEX 31 - ENERGY RELATED ENVIRONMENTAL IMPACT OF BUILDINGS, 2004).

Cause and effect chains are usually longer and more intricate than it appears to be. In complex systems such as cities, such networks tend to be extremely complex. To study the potential final impact of an environmental load, laboratory models have been developed (FEMIA; MOLL, 2005). These models, however, can only provide simplified representations of actual interactions in the environment, which comprehend thousands of living species and a wide range of conditions surrounding them. To measure the final impacts of cause and effect chains is more difficult than measuring their intermediate impacts or the direct effects of environmental loads, given the unavailability of sufficiently robust models (UNITED NATIONS ENVIRONMENT PROGRAMME, 2003).

Due to these uncertainties in the forecasting of final environmental impacts, most studies on urban metabolism are limited to environmental load estimates (material flows). Such results still are mostly descriptive and quantitative.

A single study was found that aimed to estimate the final impacts from the procedures used to associate the results of material flows to the tools (software applications), which are appropriate to Life Cycle Assessments (VAN DER VOET et al, 2005).

In the study carried out by Kuhn (2014), the author chose not to convert the result into potential impacts as it was considered that the uncertainties and inaccuracies associated with such procedures would upset any efforts to accurately estimate the material flows in the city of Feliz. Therefore, the local metabolism was assessed using an analytical or comparative approach.

The analytical assessment was made in different ways, in order to identify the sectors in the city where initiatives promoting the closing of the material cycles were observed. It was also possible to identify specific critical flows, with a major contamination potential. With regard to comparative analysis between cities, some 
indicators proved to be useful. Figure 2 illustrates a comparison of Domestic Material Consumption values (DMC). It should be pointed out that this figure should be examined with caution, as the identified available studies were carried out by different authors at different times. Direct comparisons would require the use of a shared common data source.

Finally, results can also be assessed using categories, such as composition, which were created and described in the previous section.

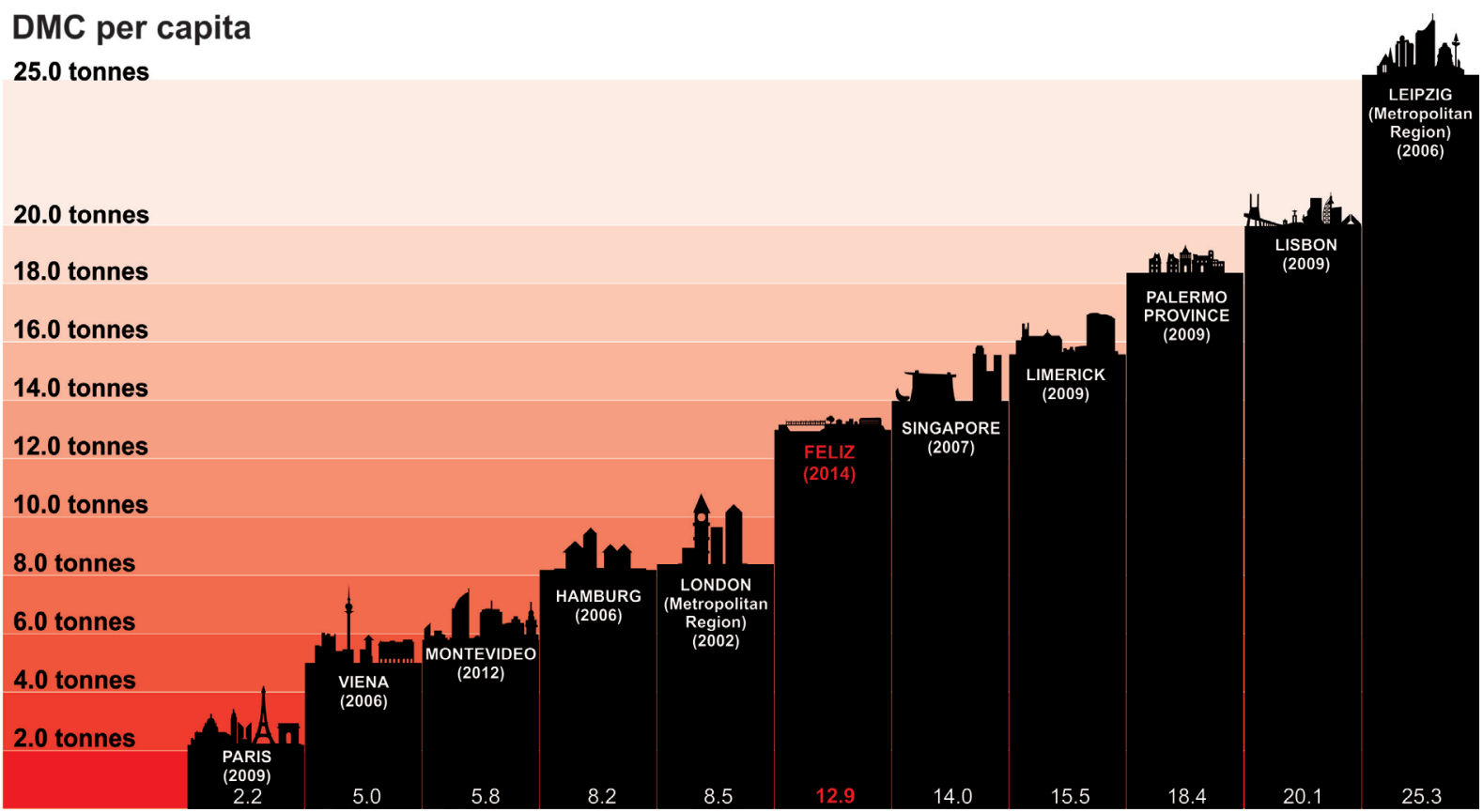

Figure 2

Comparison of DMC indicators estimated by previous urban metabolism studies (tonnes per capita).

Source: authors.

\section{Urban metabolism and environmental decisions}

The variety of potential uses of urban metabolism studies to support environmental decisions should be added to the wealth of information such studies provide. However, it was observed that most urban metabolism studies tend to be restricted to the scientific environment, with just a few examples of applications to support decision-making processes.

To make the analysis presented in this section more objective, three main possible activities were first identified: city management, planning and design. They are unique, complementary and intrinsically associated with urban development. Using these activities as a reference, the following subsections discuss the potential use of the results of urban metabolism studies. 


\section{Support to city management}

The application of results of urban metabolism to city management seem to be the most obvious, as many flows are directly related to infrastructure and daily management procedures. These include the investigation of the flows of solid urban waste, construction and demolition waste, wastewater and sewage. In the Brazilian scenario, it can be observed that city management responsibilities are, in many regions, split among different offices in charge of specific city functions and also involved in the planning of future initiatives. In this case, each office would most likely be interested in the results of very specific flows, and detailed results would provide better information than highly aggregated results.

\section{Support to planning activities}

Urban planning activities are usually distributed among different administrative levels, at national, regional, macrolocal, mesolocal and microlocal scales (SOUZA, 2010). Decision-making support to the activities associated with each level of decision calls for the use of different types of information.

On a national and a regional planning scale, aggregated metabolism results can be used as indicators to monitor and compare one city with another, as well as to compare local indicators with regional and national indicators. In addition, if applied to a wider scale, this would provide a better understanding of the role of different city profiles on the regional and/or national network, with reference to resource supply and consumption. This would allow planners to design customized environmental and development policies.

On a local planning scale, one of the possibilities for applying the results of metabolism studies is to integrate these to environmental reports, so that the studies can help to support the development of plans and local policies. In this sense, a particularly promising avenue seems to be the association of metabolism studies to the process of drafting the local Agenda $\mathbf{2 1}$ or similar strategic plans. Three examples in this direction can be found in the literature, the most recent being the ANAFLUMPA project (Analysis of Material Flows in Palermo), counting with the participation of several local corporations, including the city of Palermo and the Regional Environmental Protection Agency (FEMIA; FALCITELLI, 2009).

Results of metabolism studies can also be used to forecast the effect of changes in regional flows. To achieve 
this, techniques can be used to create scenarios associated with the observed trends, such as the increase or reduction of material flows over time.

\section{Project support}

Regarding the use of material flow results in urban design, the literature makes reference to a project developed by students of architecture at Massachussets Institute of Technology to support the sustainable reconstruction of New Orleans (FERNANDEZ; QUINN, 2007).

According to Dielmann (2009), urban projects on a microlocal scale play a key role in the reduction of resource requirements and waste generation during construction processes, since the choice of different construction alternatives, in terms of techniques and materials may determine different flow magnitudes and levels of environmental impact. In addition, the characteristics of buildings may also affect a range of flows, particularly energy flows. The importance of the environmental effects of different urban projects can be estimated when we consider that the largest share of natural resources extracted by man is taken up by civil construction, a sector that is one of the major energy users and greenhouse gases emitters in the world (UNITED NATIONS ENVIRONMENT PROGRAM$M E, 2003)$.

According to Deilmann (2009), the metabolism approach can be included in the debate on the influence of the morphology of the city on resources consumption and waste generation.

\section{Possibilities and challenges in the characterization of the metabolism of Brazilian municipalities}

Even though the potential uses of the results of studies on urban metabolism to support environmental decisions are well known, in Brazil this field is still in its early development stages. The two identified initiatives (CONKE; FERREIRA, 2015; KUHN, 2014) originated in academia and not from an empirical need of information on the part of city management offices.

This could give rise to some concern, as indicated by the tendency of governments to not compute environmental costs, such as those made possible by meta- 
bolism studies, in city decision-making processes. The lack of interest shown by administrators is likely to be connected to the type (material flows) and the site (other municipalities) that manifest the environmental impacts of the flows characterized by metabolism studies.

Urban environmental priorities in Brazil seem to be different from those found in the European Union, for example. According to Niza, Rosado and Ferrão (2009), the sustainable management of natural resources has received special attention in EU environmental and developmental policies, which is attested by the fact that many of the key policy documents in this organization tackle this issue.

Costa (1999) claims that the discussion on urban environmental issues in Brazil seems to focus on specific items, such as basic sanitation, health services and quality of life. This results from the fact that most Brazilian cities are yet to provide a minimal level of access to major urban goods and services. Acselrad (1999) adds that approaches centered on quality of life issues may, in some cases, be the result of an attempt to promote an image that highlights a given city's environmental, aesthetic and cultural heritage so that it can attract international capital flows.

It can be observed that Brazilian cities still seem to be very far from making clear environmental commitments and further still from reassessing their patterns of resource use and allocation, as this would imply reassessing a large number of processes and activities that originate material flows. Whenever development patterns and the inclusion of urban requirements associated with the management of resources are questioned, this is usually associated to barriers to economic development or to improvements in the city 's quality of life. In addition, the environmental benefits of reduced resource and waste flows often go unnoticed by those that originate them.

With regard to the alternatives and methodological challenges for the development of urban metabolism studies in Brazilian settings, two possible paths are suggested by the two previous experiences. The first, in line with the work developed by Conke and Ferreira (2015), is more limited in the number of estimated material flows, but is subject to fewer restrictions concerning data acquisition and confidentiality. In addition, the data in this case seem to require very little processing apart from simple aggregation. 
The second path, in the line proposed by Kuhn (2014) and adopted in recent studies developed in Europe, provides additional information, that can be used to develop indicators, that allow the comparison of the urban metabolism of different cities. It is understood that the method can be replicated, once made easier by the use of software applications, such as the one developed by the Kuhn (2014) for the automatic conversion of data.

However, this method was only tested in a small municipality and has yet to be validated in other locals. A critical aspect of the method is associated with access restrictions to important sources of data, such as digital invoices (NF-e) provided by the state office of revenue, which are subject to tax secrecy regulations.

\section{Conclusions}

This article aimed to discuss the potential contributions of the urban metabolism concept and approach to the assessment of the cost of environmental decisions in Brazilian settings. The discussion started with a review of the literature on the relationships between the concepts of urban ecology and urban metabolism, whose origins, controversies and recent developments were presented. The review showed that the theoretical contributions that result from adopting the metabolism concept and approach in the assessment of environmental costs derive from the fact that they are grounded in consolidated theories (such as the Theory of Systems) and models (such as cause and effect models).

With regard to practical contributions, this article discussed the main benefits and possibilities of insertion of the concept in the three major activities associated with urban development: management, planning and design.

Finally, the possibilities and challenges for the characterization of metabolism in a larger number of Brazilian cities were discussed. As methodological alternatives, two different paths have been proposed: one that is simpler and faster and another that is more demanding but provides a more detailed assessment.

Concerning the challenges associated with the interest of municipal administrations in computing environmental costs in their decision-making processes, it was observed that this does not seem to be a concern by governments in the short term. 
The discussions above indicate that the following developments may be welcomed in studies of urban metabolism in Brazilian settings: a) validation of replicability and improvement of methods to be developed or customized to local settings; b) an increase in the number of cases studied, to help identify patterns and establish valid general concepts that associate urban variables with material flows; c) conduction of studies on potential practical applications and assessment of the interests of different social stakeholders and representatives of a range of city sectors.

\section{References}

ACSELRAD, H. Discursos da sustentabilidade urbana. Revista Brasileira de Estudos Urbanos e Regionais, maio. 1999. v. 1, p. 79-89.

ALBERTI, M. Measuring urban sustainability. Environmental Impact Assessment Review, 1996. v. 16 , n. 4-6, p. 381-424.

BAI, X. Industrial ecology and the global impacts of cities. Journal of Industrial Ecology, Spring. 2007. v. 11, n. 2, p. 1-6.

BROTO, V. C.; ALLEN, A.; RAPOPORT, E. Interdisciplinary perspectives on urban metabolism. Journal of Industrial Ecology, 2012. v. 16, n. 6, p. 851-861.

CIDADE, L. C. F. A questão ambiental urbana: perspectivas de análise. Anais: Encontros Nacionais da ANPUR, 1 fev. 2012. v. 6, n. 0. Available in: <http://unuhospedagem.com.br/ revista/rbeur/index.php/anais/article/view/1606>.

CONKE, L. S.; FERREIRA, T. L. Urban metabolism: measuring the city's contribution to sustainable development. Environmental Pollution, jul. 2015. v. 202, p. 146-152.

COSTA, H. Desenvolvimento urbano sustentável: uma contradição de termos? Revista Brasileira de Estudos Urbanos e Regionais, 1999. v. 2, n. 2, p. 55-71.

DEILMANN, C. Urban metabolism and the surface of the city. Guiding principles for spatial development in Germany. Berlin, Heidelberg: Springer Berlin Heidelberg, 2009, p. 1-16.

EUROSTAT. Economy-wide material flow accounts and derived indicators. A methodological guide. Luxembourg: Statistical Office of the European Union, 2001.

FEMIA, A.; FALCITELLI, F. The Anaflumpa project: economy-wide MFA at a local level - the caso of the Italian province of Palermo. In: CONACCOUNT 2008. Urban Metabolism: Measuring the Ecological City, 2009, Praga. Anais... Praga: Charles University Environment Center, 2009. p. 408-429.

FEMIA, A.; MOLL, S. Use of MFA-related family of tools in environmental policy-making: overview of possibilities, limitations and existing examples of application in practice, working paper. p.31. European Environment Agency, Copenhagen.

FERNANDEZ, J.; QUINN, D. Urban metabolism: ecologically sensitive construction for a sustainable New Orleans. Available in: <http://web.mit.edu/djq/Public/Thesis/Holcim_ April_07_David_Quinn.pdf>.

FISCHER-KOWALSKI, M. Society's metabolism. Journal of Industrial Ecology, 1998. v. 2, n. 1 , p. $61-78$. 
IEA ANNEX 31 - ENERGY RELATED ENVIRONMENTAL IMPACT OF BUILDINGS. Environmental framework. [S.I.], 2004. Available in: <http://annex31.wiwi.unikarksruhe.de/concepts. htm>.

KENNEDY, C.; HOORNWEG, D. Mainstreaming urban metabolism. Journal of Industrial Eco$\log y, 2012$. v. 16, n. 6, p. 780-782.

KENNEDY, C.; PINCETL, S.; BUNJE, P. The study of urban metabolism and its applications to urban planning and design. Environmental Pollution, 2011. v. 159, n. 8, p. 1965-1973.

KUHN, E. A. Metabolismo de um município brasileiro de pequeno porte: o caso de Feliz, RS. Porto Alegre: Universidade Federal do Rio Grande do Sul, 2014. Tese (Doutorado em Engenharia Civil). Available in: <http://www.lume.ufrgs.br/handle/10183/96657>.

MOTA, S. Planejamento urbano e preservação ambiental. Fortaleza: Edições UFC, 1981. MUNFORD, L. The city in history: its origins, its transformations, and its prospects. New York: Harcourt, Brace \& World, 1961.

NIZA, S.; ROSADO, L.; FERRÃO, P. Urban metabolism: methodological advances in urban material flow accounting based on Lisbon case study. Journal of Industrial Ecology, 2009. v. 13, n. 3 , p. 384-405.

ROGERS, R.; GUMUCHDJIAN, P. Cidades para um pequeno planeta. 1. ed. São Paulo: Gustavo Gili (BR), 2014.

SILVA, S. Indicadores de sustentabilidade urbana: as perspectivas e as limitações da operacionalização de um referencial sustentável. São Carlos: Centro de Ciências Exatas e de Tecnologia, Universidade Federal de São Carlos, 2000. Dissertação (Mestrado em Engenharia Urbana).

SOUZA, M. L. De. Mudar a cidade: uma introdução ao planejamento e à gestão urbanos. 6. ed. Rio de Janeiro: Bertrand Brasil, 2010.

UNITED NATIONS ENVIRONMENT PROGRAMME. Evaluation of environmental impacts in life cycle assessment. [S.I.], 2003. Available in: <http://rosinant.antenna.nl/scnet/fmpro?$\mathrm{db}=$ scnetres_.fp3\&format=rescatpub.html\&-view $>$.

UNITED NATIONS HUMAN SETTLEMENTS PROGRAMME - UN-HABITAT. The Habitat Agenda. Instanbul: UN-HABITAT, 1996.

VAN DER VOET, E. et al. Policy Review on Decoupling: Development of indicators to assess decoupling of economic development and environmental pressure in the EU-25 and AC-3 countries. CML report 166. Leiden, Holanda: European Community, 2005.

WOLMAN, A. The metabolism of cities. Scientific American, 1965. v. 213, p. 179-190. 